\title{
Karakteristik Hidrokimia Akibat Pengaruh Formasi Batuan pada Mata Air Panas Di Desa Wukirharjo, Kecamatan Parengan, Kabupaten Tuban, Jawa Timur
}

\author{
Sepridawati Siregar*, Desi Kiswiranti, dan M. Jamaludin \\ Jurusan Teknik Geologi, Institut Sains \& Teknologi AKPRIND, Jl Kalisahak No. 28 Yogyakarta, Indonesia \\ E-mail: *sepridawati@akprind.ac.id
}

Masuk:30 November 2017 Direvisi : 12 Desember $2017 \quad$ Disetujui : 21 Desember 2017

\begin{abstract}
Abstrak: Penelitian dilakukan di desa Wukirharjo, Kecamatan Parengan, Kabupaten Tuban, Jawa Timur tentang pengaruh formasi batuan terhadap karakteristik hidrokimia sumber mata air panas dengan suhu mencapai $500^{\circ} \mathrm{C}$ di Wana Wisata Prataan. Penelitian ini bertujuan untuk menentukan parameter fisika dan kimia yang terdapat pada sumber mata air panas dan selanjutnya dianalisis hubungan kandungan logam yang dimiliki sumber mata air panas terhadap formasi batuan di daerah Kecamatan Parengan. Pengujian bau dan rasa langsung dilakukan di lokasi penelitian dengan sedikit berbau sulfur dan tidak berasa, sedangkan nilai $\mathrm{pH}$ adalah 6,5yang termasuk pada kategori asam. Kandungan sulfur pada mataair panas ini cukup tinggi yaitu $153 \mathrm{mg} / \mathrm{L}$ dan nilai kesadahan $65,8 \mathrm{mg} / \mathrm{L}$ tetapi masih dibawah baku mutu air bersih yang ditetapkan. Sumber mata air panas yang tersingkap di daerah Wukirharjo tersusun atas batugamping dan batupasir kuarsa yang termasuk dalam zona rembang. Dimana zona ini merupakan formasi ngrayong yang terbentuk karena adanya silika yang didominasi oleh logam Fe dengan konsentrasi 10,554 mg/L dan Al dengan konsentrasi 4,552 mg/L. Sumber mata air panas ini memiliki TDS rendah dengan nilai $8,3 \mathrm{mg} / \mathrm{L}$ dan digolongkan sebagai air lunak (soft water), sehingga masih layak sebagai air pemandian.
\end{abstract}

Kata kunci: Hidrokimia, batuan, mataair panas

\begin{abstract}
This research was done at Wukirharjo village, Parengan subdistrict, Tuban district, Jawa Timur which is about the influence of rocks formation to characteristic of hydrochemical in hot spring with temperature up to $500^{\circ} \mathrm{C}$ at Wana Wisata Prataan. The purpose of this research is to determine physical and chemical parameter at hot spring and then analyze relation of metal component to rocks formation at Kecamatan Parengan. The direct analysis of odor and taste was done at research location with the result is sulphur aroma and without taste, and the pH value is 6.5. Sulphur component at hot spring is high concentrate that is $153 \mathrm{mg} / \mathrm{L}$ and hardness is $65,8 \mathrm{mg} / \mathrm{L}$. This value is under standart value of clean water. The hot spring is consist of limestone and sand that is in rembang zone. This zone was ngrayong formation that was formed from silica with Fe of 10,554 $\mathrm{mg} / \mathrm{L}$ and Al of 4,552 $\mathrm{mg} / \mathrm{L}$. This hot spring has low TDS with 8,3 $\mathrm{mg} / \mathrm{L}$ and classfied as soft water so it is still suitable for bathe water.
\end{abstract}

Keywords: Hydrochemical, rocks, hot spring

\section{PENDAHULUAN}

Mataair panas merupakan suatu sumber air yang banyak dimanfaatkan baik oleh penduduk setempat maupun oleh para wisatawan. Salah satu sumber air panas di Indonesia ditemukan di Desa Wukirharjo, Kecamatan Parengan, Kabupaten Tuban, Jawa Timur, terletak pada ketinggian 25 m dpl (di atas permukaan laut) dan curah hujan rata-rata $2.030 \mathrm{~mm} / \mathrm{tahun}$ dan termasuk kelas hutan jenis jati.

Mataair panas di Desa Wukirharjo tersebut mengandung belerang yang langsung dialirkan dari sumber air panas yang berasal dari sekitar hutan jati. Kandungan belerang yang cukup tinggi pada mataair panas tersebut, dipercaya oleh masyakarakt sekitar dan wisatawan memiliki khasiat untuk mengobati penyakit kulit.

Menurut peraturan Menteri Kesehatan RI Nomor 416/Menkes/Per/IX/1990 tentang syarat-syarat dan pengawasan kualitas air ada beberapa parameter yang harus ditinjau, yaitu parameter fisik, kimia, radioaktifitas, dan mikrobiologis. Air yang memenuhi parameter fisik adalah air yang tidak berbau, tidak berasa, tidak 
berwarna, tidak keruh dan dengan suhu yang sebaiknya di bawah suhu udara sedemikian rupa sehingga menimbulkan rasa nyaman dan jumlah zat padat terlarut (Total Dissolved Solid / TDS) yang rendah. Dari segi parameter kimia, air yang baik adalah air yang tidak tercemar secara berlebihan oleh zat-zat kimia yang berbahaya bagi kesehatan, antara lain $\mathrm{Hg}, \mathrm{Al}, \mathrm{As}, \mathrm{Ba}, \mathrm{Fe}, \mathrm{F}, \mathrm{Ca}$, derajat keasaman, dan zat kimia lainnya. pH yang dianjurkan untuk air bersih berkisar antara 6,5-9 [1].

Parameter hidrokimia air juga ditentukan oleh formasi batuan yang menyusun daerah penelitian. Hasil penelitian Listyani (2009) menyatakan bahwa mata air panas yang muncul di Parangwedang dikontrol oleh porositas antar butir dan rekahan [2]. Batuan gamping yang merupakan Formasi Nglanggran memiliki pengaruh terhadap keberadaan beberapa unsur kimia pada air panas yang diteliti.

Berdasarkan beberapa masalah di atas, maka penelitian ini perlu dilakukan untuk uji parameter fisika dan kimia. Hasil yang telah didapatkan dari uji beberapa parameter tersebut, akan dapat menjelaskan karakteristik dari sumber mataair panas yang berada di Desa Wukirharjo.

\section{METODOLOGI}

Penelitian dilakukan di wana wisata Prataan pada bulan Juni-September 2017 yang Terletak di Desa Wukirharjo, Kec. Parengan, Kab. Tuban, Jawa Timur dengan titik koordinat 111 $30^{\circ}-112^{\circ} 35^{\prime}$ BT $6^{\circ} 40^{\prime}-$ $7^{\circ} 18^{\prime}$ LS. Dapat dilihat pada peta Gambar 1.

Pendekatan penelitian yang dilakukan adalah dengan cara penelitian secara langsung ke lapangan didahului dengan melakukan survey lokasi kemudian dilanjutkan dengan pengambilan data geologi daerah Wukirharjo dan sekitarnya, mengukur langsung (bau, rasa dan $\mathrm{pH}$ ) dan pengambilan sampel air panas sebanyak 1 liter. Sampel air yang diambil langsung dari lokasi penelitian terdiri dari 3 sampel, yaitu sampel 1, sampel 2 dan sampel 3 yang diambil dari 3 mataair panas yang berbeda. Ketiga sampel tersebut dimasukan ke dalam botol drigen dan dibawa ke laboratorium untuk dianalisa di Laboratorium Penguji dan Kalibrasi BBTKL PP Yogyakarta. Penelitian ini juga ditambah data dari data sekunder, yaitu data dari peneliti terdahulu, seperti data geologi, data geokimia yang dapat melengkapi data penelitian.

Untuk penentuan bau dan rasa menggunakan metode pengamatan organoleptik, sedangkan untuk nilai TDS digunakan metode Gravimetri dengan menggunakan timbangan analitik. Nilai pH ditentukan dengan $\mathrm{pH}$ meter, nilai warna menggunakan alat Kalorimeter, sulfat dan kesadahan menggunakan alat Spektrofotometer UV-vis dan untuk penentuan kandungan logam digunakan alat Flame-Atomic Absorption Spectroscopy (AAS), merk Shimadzu type 6800AA.

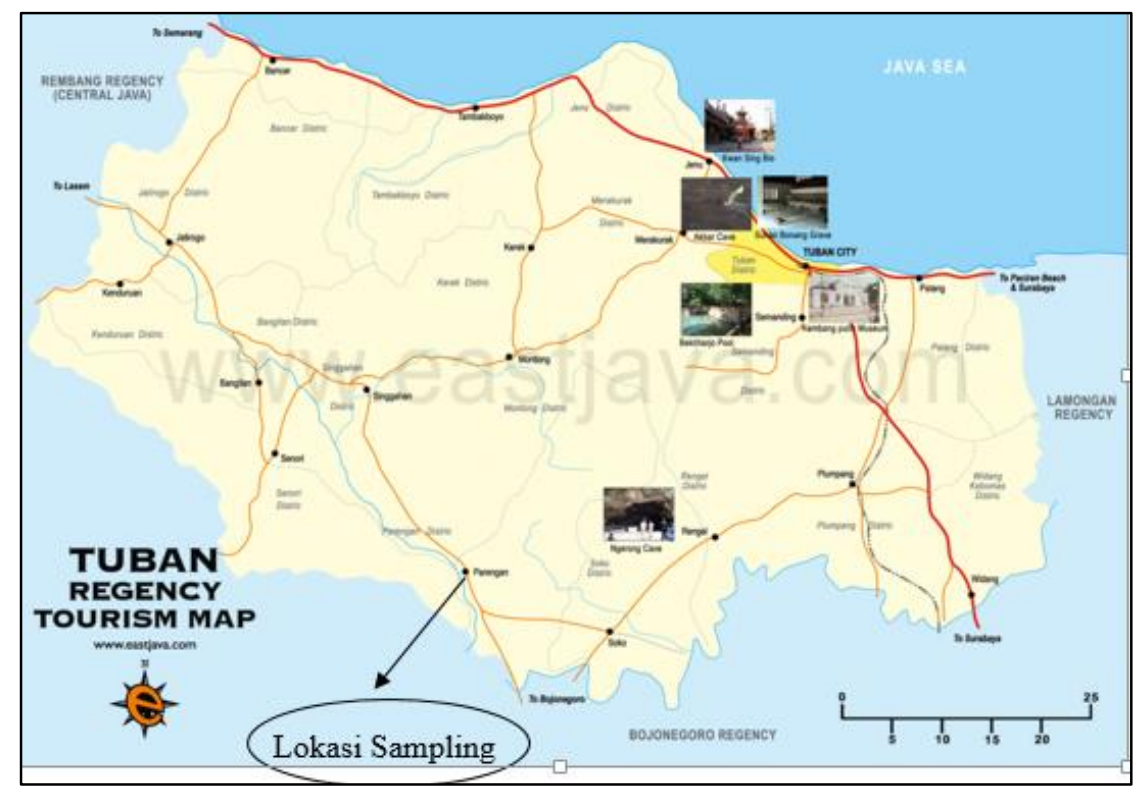

Gambar 1. Peta Lokasi Sampling (Sumber: Muslim, 2011) 


\section{HASIL DAN PEMBAHASAN}

\section{Kondisi Geologi Daerah Penelitian}

Daerah pemetaan termasuk kedalam lajur Rembang (Gambar 2). Lajur ini pada umumnya merupakan endapan paparan yang kaya akan batuan karbonat dan jarang dijumpai endapan piroklastik. Lipatan dan sesar dapat diamati pada batuan Oligo-Miosen sampai Pliosen. Umumnya sumbu antiklin berarah baratlaut-tenggara dengan sudut kemiringan antara 10 sampai 30 derajat dan berkembang pada formasi Kujung dan Tuban. Sesar terdapat pada batuan sedimen berumur Oligo-Miosen sampai Pliosen dan umumnya berarah timurlaut-baratdaya dan baratlaut-tenggara.

Stratigrafi daerah penelitian disusun atas enam satuan batuan tidak resmi,yaitu dari tua ke muda: satuan batugamping orbitoid (Formasi Tawun) diendapkan pada Miosen Awal Â- Miosen Tengah, satuan batupasir kuarsa (Formasi Ngrayong) diendapkan pada Miosen Tengah, satuan batugamping packestone (Formasi Bulu) diendapkan pada Miosen Tengah, satuan batulempung napalan (Formasi Wonocolo) diendapkan pada Miosen Tengah Â- Miosen Akhir, satuan batugamping wackestone (Formasi Ledok) diendapkan pada Miosen Akhir Pliosen, Satuan Napal (Formasi Mundu) diendapkan pada Pliosen [3].

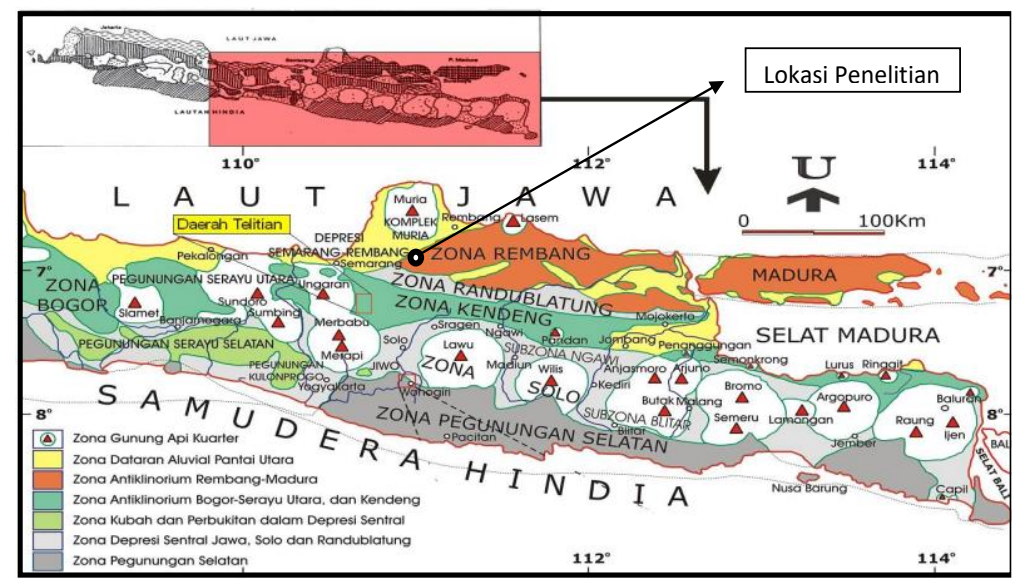

Gambar 2. PetaLokasi Penelitian berada pada Zona Rembang [4]

Litologi daerah penelitian disekitar Wana Wisata Prataan, terdiri dari batugamping (Gambar 3a) dan batupasir kuarsa (Gambar 3b) dengan mineral utamanya adalah kalsit. Pembentukan kalsit dalam batugamping berawal dari mineral aragonit $\left(\mathrm{CaCO}_{3}\right)$, yang merupakan mineral metastable karena pada kurun waktu tertentu dapat berubah menjadi kalsit $\left(\mathrm{CaCO}_{3}\right)$. Mineral lain yang ditemukan dalam jumlah kecil adalah $\operatorname{Siderit}(\mathrm{FeCO})$, ankarerit $\left(\mathrm{Ca}_{2} \mathrm{MgFe}\left(\mathrm{CO}_{3}\right)_{4}\right)$, dan magnesit $\left(\mathrm{MgCO}_{3}\right)$. Sedangkan batu pasir terbentuk dari sedimentasi dari butiran-butiran pasir yang terbawa oleh aliran sungai, angin, dan ombak dan akhirnya terakumulasi pada suatu tempat. Ukuran butiran dari batu pasir ini 1/16 hingga 2 milimeter. Batupasir kuarsa adalah batu pasir yang $90 \%$ butirannya tersusun dari kuarsa.

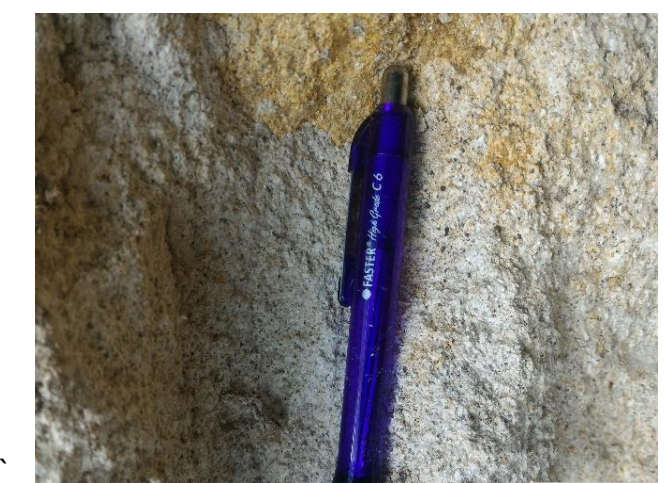

a)

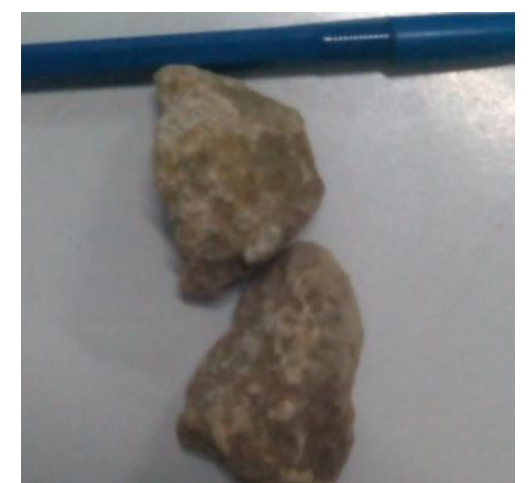

b)

Gambar 3. Litologi Daerah Penelitian terdiri dari: a). Batugamping dan b). Batupasir kuarsa. 


\section{Analisis Sampel Penelitian}

Pengukuran langsung di lapangan untuk parameter bau, rasa, warna dan $\mathrm{pH}$. Sedangkan untuk parameter TDS, kesadahan, Sulfur dan kandungan logam dilakukan di laboratorium. Hasil analisa untuk parameter bau, rasa, warna, TDS, $\mathrm{pH}$, kesadahan dan sulfat dapat dilihat pada Tabel 1.

Tabel 1. Nilai bau, rasa, warna, TDS, $\mathrm{pH}$, kesadahan dan sulfat dari sampel air sumber mata air panas

\begin{tabular}{|c|c|c|c|c|c|c|}
\hline \multirow{2}{*}{ Parameter } & Satuan & Hasil analisis & Hasil analisis & Hasil analisis & Rata-rata & \multirow{2}{*}{$\begin{array}{l}\text { Kadar Maks. } \\
\text { Menkes RI }^{\mathrm{a}}\end{array}$} \\
\hline & & Sampel 1 & Sampel 2 & Sampel 3 & Hasil analisis & \\
\hline $\mathrm{Bau}$ & - & Sedikit bau sulfur & Sedikit bau sulfur & Sedikit bau sulfur & Sedikit bau sulfur & Tdk berbau \\
\hline Rasa & - & Tdk berasa & Tdk berasa & Tdk berasa & Tdk berasa & Tdk berasa \\
\hline Warna & Skala TCU & 0,5 & 0,4 & 0,6 & 0,5 & 15 \\
\hline TDS & $\mathrm{mg} / \mathrm{L}$ & 8,5 & 7,4 & 9,0 & 8,3 & 1000 \\
\hline $\mathrm{pH}$ & - & 6,5 & 6,5 & 6,5 & 6,5 & $6,5-9,0$ \\
\hline Kesadahan & $\mathrm{mg} / \mathrm{L}$ & 65,5 & 67,3 & 64,7 & 65,8 & 500 \\
\hline Sulfur & $\mathrm{mg} / \mathrm{L}$ & 150 & 155 & 154 & 153 & 400 \\
\hline
\end{tabular}

Nilai parameter bau dan rasa dari sampel sumber mataair panas Wana Wisata Prataan, memiliki nilai sedikit berbau sulfur dan tidak berasa. Data yang didapatkan dariPengujian bau dan rasa dengan metoda pengamatan Organoleptik yaitu penciuman dengan indra pencium dan perasa dari aroma dan rasa yang ditimbulkan dalam sampel, dapat dilihat pada Tabel 1.Sumber mataair panas yang berbau sulfur ini sesuai dengan kandungan sulfur yang cukup tinggi terukur yaitu $153 \mathrm{mg} / \mathrm{L}$. Begitu juga untuk nilai kesadahan $65,8 \mathrm{mg} / \mathrm{L}$. walaupun nilai sulfur dan kesadahan dalam sampel air cukup tinggi, namun masih memenuhi syarat nilai untuk air bersih. Air panas yang mengandung sulfur tersebut dipercaya oleh masyarakat setempat dan wisatawan berkhasiat untuk mengobati penyakit kulit. Untuk nilai warna dan TDS yang terukur cukup rendah yaitu $0,5 \mathrm{TCU}$ dan $8,3 \mathrm{mg} / \mathrm{L}$. Berdasarkan klasifikasi air tanah, sampel sumber mataair panas tersebut dilihat dari nilai TDS yang sangat rendah dibandingkan dengan baku mutu merupakan air tanah sebagai air lunak (soft water), yaitu air dengan nilai TDS yang < $100 \mathrm{mg} / \mathrm{L}[5]$.

Nilai $\mathrm{pH}$ pada sampel air adalah 6,5, dimana digolongkan pada $\mathrm{pH}$ asam yaitu $\mathrm{pH}<7$. Menurut syarat air bersih, $\mathrm{pH}$ yang dianjurkan sebagai syarat air bersih berkisar antara 6,5-9, sehingga sampel air tersebut memenuhi syarat nilai $\mathrm{pH}$ untuk air bersih. Untuk unsur-unsur logam yang diuji adalah seng $(\mathrm{Zn})$, tembaga $(\mathrm{Cu})$, besi $(\mathrm{Fe})$, aluminium $(\mathrm{Al})$ dan timbal $(\mathrm{Pb})$. Hasil pengujian kandungan logam dapat dilihat pada Tabel 2.

Tabel 2. Nilai konsentrasi logam dari sampel air sumber mata air panas

\begin{tabular}{|c|c|c|c|c|c|c|}
\hline \multirow{2}{*}{ Parameter } & Satuan & Hasil analisis & Hasil analisis & Hasil analisis & Rata-rata & \multirow{2}{*}{$\begin{array}{l}\text { Kadar Maks. } \\
\text { Menkes RI }^{\mathrm{a}}\end{array}$} \\
\hline & & Sampel 1 & Sampel 2 & Sampel 3 & Hasil analisis & \\
\hline $\mathrm{Zn}$ & $\mathrm{Mg} / \mathrm{L}$ & 8,535 & 7,904 & 8,217 & 8,220 & 15 \\
\hline $\mathrm{Cu}$ & $\mathrm{Mg} / \mathrm{L}$ & 8,643 & 9,011 & 8,869 & 8,841 & 1,0 \\
\hline $\mathrm{Fe}$ & $\mathrm{Mg} / \mathrm{L}$ & 10,522 & 10,476 & 10,665 & 10,554 & 1,0 \\
\hline $\mathrm{Al}$ & $\mathrm{Mg} / \mathrm{L}$ & 4,572 & 4,329 & 4,754 & 4,552 & 0,2 \\
\hline $\mathrm{Pb}$ & $\mathrm{Mg} / \mathrm{L}$ & 0,018 & 0,022 & 0,020 & 0,020 & 0,05 \\
\hline
\end{tabular}

Tembaga $(\mathrm{Cu})$ adalah salah satu mineral yang terkandung di dalam batuan intrusi selain $(\mathrm{Au}, \mathrm{Pb}, \mathrm{Zn}$, dan Ag). Data yang didapatkan dari pengujian AAS (Atomic Absorption Spectroscopy) dapat dilihat pada Tabel 2.

Proses pembentukan $\mathrm{Cu}$ akibat adanya batuan terobosan yang terdiri dari granit dan granodiorit yang berperan sebagai batuan pembawa mineral yang berhubungan dengan magma dan menembus lapisan sedimen, dimana pada tahap akhir kegiatan intrusi terjadi peningkatan konsentrasi elemen-elemen tertentu pada bagian atas, baik gas maupun cair dan bergerak melalui pori-pori / retakan-retakan, karena pengaruh tekanan dan temperatur maka terjadilah proses kristalisasi [6]. Aktivitas hidrotermal yang tinggi pada titik pengambilan sampel menyebabkan batuan terobosan pada batuan intrusi dengan cepat membentuk proses kristalisasi.

Magma disusun oleh bahan yang berupa gas seperti $\mathrm{H}_{2} \mathrm{O}$ dan $\mathrm{CO}_{2}$ dan bahan yang bukan gas yang terdiri dari Si, O, Fe, Al, Ca, K, Mg, dan Na. Daerah Parengan, Tuban, termasuk dalam zona Rembang dengan demikian sangat memungkinkan bahwa adanya kandungan besi $(\mathrm{Fe})$ pada batuan yang berada di daerah Wana Wisata Prataan. Data yang didapatkan dari pengujian sampel dapat dilihat pada Tabel 2. 
Lokasi penelitian tersusun atas batupasir kuarsa dimana kuarsa memiliki senyawa kimia yang terdiri dari satu bagian silikon dan dua bagian oksigen atau biasa disebut silikon dioksida $\left(\mathrm{SiO}_{2}\right)$, sehingga unsur pembentukan kuarsa adalah silikat. Menurut Loughnan (1969), dalam struktur silikat, oksigen merupakan anion yang paling penting [7]. Ikatan antara kation dan oksigen meningkat sesuai dengan jarak radius kation dan oksigen maka ikatan mineralnya akan semakin kuat. Mineral silikat didominasi oleh unsur Si, Al, dan O ditambah unsur-unsur lain seperti $\mathrm{K}, \mathrm{Na}, \mathrm{Ca}, \mathrm{Mg}$, dan Fe. Silikat banyak terkandung pada lokasi penelitian sehingga Fe banyak terbentuk di lokasi tersebut.

Salah satu unsur yang mendominasi mineral silikat adalah Alumunium (Al), maka perlu adanya analisis logam pada sampel air tersebut. Kecilnya kandungan logam Al pada sampel menandakan bahwa batuan kuarsa di daerah penelitian kurang didominasi oleh Alumunium (Al). Mineral silikat yang paling banyak mendominasi untuk batuan andesit di daerah ini adalah besi $(\mathrm{Fe})$ yang telah dijelaskan sebelumnya.

Untuk kandungan logam Seng (Zn) juga cukup tinggi pada lokasi penelitian yaitu 8,22 mg/L. hal ini menunjukan bahwa batuan penyusun daerah penelitiaan juga cukup tinggi mengandung logam Seng (Zn).

Logam berat merupakan unsur alami dari kerak bumi, adanya aktifitas beberapa gunung apiyang beradadi tuban (Gunung Mundu,

Gunung Gesikan, Gunung Sentul, Gunung Sambengan,Gunung Katong, Gunung Tapakan, Gunung Maindu, Gunung Kendil, Gunung Leran, Gunung Nganten, Gunung Ngimbang, Gunung Galang dan Gunung Singget)memungkinkan terdapatnya unsur-unsur seperti $\mathrm{Pb}, \mathrm{Zn}, \mathrm{Cu}, \mathrm{Fe}$, dan $\mathrm{Al}$.

Kandungan Al dan Fe sebagai pendominasi terbentuknya silika pada batupasir kuarsa menandakan bahwa daerah penelitian tersusun atas batuan kuarsa yang merupakan anggota dari Formasi Ngrayong.Formasi Ngrayong disusun oleh batupasir kwarsa dengan perselingan batulempung, lanau, lignit, dan batugamping bioklastik. Pada batupasir kwarsanya kadang-kadang mengandung cangkang moluska laut. Lingkungan pengendapan Formasi Ngrayong di daerah dangkal dekat pantai yang makin ke atas lingkungannya menjadi littoral, lagoon, hingga sublittoral pinggir [8].

Timbal $(\mathrm{Pb})$ merupakan salah satu logam berat yang membahayakan bagi kesehatan manusia. Untuk mengetahui apakah air yang berasal dari sumber mata air panas di daerah penelitian telah tercemar oleh $\mathrm{Pb}$, maka perlu dilakukan analisis. Tabel 2 memperlihatkan bahwa pada sampel hanya sedikit mengandung logam $\mathrm{Pb}$ yaitu 0,020 mg/L. Berdasarkan Permenkes No.416/Menkes/Per/IX/1990 standar maksimum kadar logam timbal $(\mathrm{Pb})$ dalam air bersih dan air minum adalah $0,05 \mathrm{mg} / \mathrm{L}$. oleh karena itu masih memenuhi syarat nilai untuk air bersih. Sedangkan untuk logam $\mathrm{Cu}, \mathrm{Fe}$ dan $\mathrm{Al}$ memiliki nilai melebihi baku mutu air bersih Permenkes No.416/Menkes/Per/IX/1990 [9,10].

Berdasarkan data diatas, mataair panas daerah Wana Wisata Prataan tidak dapat digunakan sebagai kebutuhan air bersih untuk bahan baku air minum dan keperluan sehari-hari. Oleh karena itu oleh pemerintah dan masyarakat setempat mataair panas tersebut dijadikan tempat wisata pemandian karena mengandung sulfur (yaitu $153 \mathrm{mg} / \mathrm{L}$ ) yang dipercaya oleh masyarakat setempat dan wisatawan memiliki khasiat untuk mengobati penyakit kulit.

\section{KESIMPULAN}

Sumber mata air panas yang berada di desa Wukirharjo, Kecamatan Parengan, Kabupaten Tuban, Jawa Timur berasal dari adanya aktivitas beberapa gunung api yang berada di Tuban.Litologi daerah penelitian disekitar Wana Wisata Prataan, terdiri dari batugamping dan batupasir kuarsa. Kandungan Al dan Fe sebagai pendominasi terbentuknya silika pada batupasir kuarsa menandakan bahwa daerah penelitian tersusun atas batuan kuarsa yang merupakan anggota dari Formasi Ngrayong.

Berdasarkan nilai TDS yang didapatkan, air yang berasal dari sumber mataair panas tersebut tergolong air lunak (soft water), dengan nilai TDS $8,3 \mathrm{mg} / \mathrm{L}$.

mataair panas daerah Wana Wisata Prataan tidak dapat digunakan sebagai kebutuhan air bersih untuk bahan baku air minum dan keperluan sehari-hari. Oleh karena itu oleh pemerintah dan masyarakat setempat mataair panas tersebut dijadikan tempat wisata pemandian karena mengandung sulfur (yaitu $153 \mathrm{mg} / \mathrm{L}$ ) yang dipercaya oleh masyarakat setempat dan wisatawan memiliki khasiat untuk mengobati penyakit kulit.

\section{DAFTAR PUSTAKA}

[1] Slamet J S 2002 Kesehatan Lingkungan, (Yogyakarta: Gajah Mada University Press)

[2] Listyani RA T 2009 Hidrokimia dan Geologi Air Panas Daerah Parang Wedang, KabupatenBantul, Yogyakarta, Rekayasa Teknologi Industri dan Informasi, Yogyakarta.

[3] Irysal M F P 2012 Geologi Daerah Wukihajro Dan Sekitarnya, Kecamatan Parengan, Kabupaten Tuban, Jawa Timur, Undergraduate Theses, Institut Teknologi Bandung. 
46 | Sepridawati Siregar, dkk., Karakteristik Hidrokimia Akibat Pengaruh Formasi Batuan....,

[4] Bemmelen van R W 1949 The Geology of Indonesia, Martinus Nyhoff, The Hague Nederland.

[5] Tyas D J 2004 Proses Geokimia Air Tanah pada Penentuan Kualitas Air Tanah Berdasarkan Kandungan Unsur-unsur Mayor, BATAN.

[6] Toreno E T 2009 Mineralisasi Emas Epitermal di Wilayah Lubuk Gadang, Solok Selatan, Sumatera Barat, Buletin Sumber Daya Geologi, No. 1,Vol. 4, Badan Geologi - Kementerian Energi dan Sumber Daya Mineral.

[7] Loughnan F C 1969 Chemical Weathering of the Silicate Minerals (Amsterdam: Elsevier)

[8] Setyobudi, P T 2009 Geologi Zona Rembang, https://ptbudie.wordpress.com/2009/geologi-zonarembang/. Teknik Geologi Universitas Diponegoro, Diunduh 11 Februari 2015.

[9] Pringgoprawiro H 1983 Biostratigrafi dan Paleogeografi Cekungan Jawa Timur Utara, Suatu Pendekatan Baru, Institut Teknologi Bandung.

[10] Syahputra, Benny. 2009. Perancangan Trickling Filter Dengan Media Batu Apung Sebagai Upaya Penurunan Salinitas Air Payau (Studi Kasus Intrusi Air Laut Di Semarang). Jurnal Studi Lingkungan. 1(1): 47-56 